\title{
Multi-cultural education-oriented digital teaching materials to improve students' pluralist attitudes
}

\author{
Uswatun Hasanah *, Arita Marini, Arifin Maksum \\ Department of Elementary Teacher Education, Universitas Negeri Jakarta. \\ Jl. Rawamangun Muka, RT.11/RW.14, Rawamangun, Pulo Gadung, Kota Jakarta Timur, 13220, Indonesia \\ * Corresponding Author. E-mail: uswatunhasanah@unj.ac.id
}

Received: 5 November 2020; Revised: 15 November 2020; Accepted: 5 December 2020

\begin{abstract}
This study aims to analyse the effectiveness of digital teaching materials oriented to multi-cultural education in improving students' pluralist attitudes. The type of research method used is a quantitative method with a quasi-experimental design and a one-group pretest-posttest design with a control group design. The sample used was 108 grade V elementary school students in Setiabudi sub-district selected by the probability sampling technique. The study proves that the use of digital teaching materials oriented to multi-cultural education has a significant value so that it is effectively used in improving students' pluralistic attitudes. This digital teaching material allows students to analyse moral values conveyed through story content. The results of this study can provide contributions and solutions for education practitioners to instil multi-cultural education since elementary school age to create a pluralist generation of youth with diversity.
\end{abstract}

Keywords: digital teaching material, multi-cultural education, students' pluralist attitudes

How to Cite: Hasanah, U., Marini, A., \& Maksum, A. (2021). Multi-cultural education-oriented digital teaching materials to improve students' pluralist attitudes. Jurnal Prima Edukasia, 9(1), 118-126. doi:https://doi.org/10.21831/jpe.v9i1.35503

\section{Introduction}

As a country whose society is pluralistic, Indonesia consists of various ethnicities, races, customs, groups, groups and religions, and social strata. Conditions and situations like this are normal as long as these differences are realised and lived out. However, when these differences arise and become a threat to life harmony, these differences become problems that must be resolved. Multicultural, multiracial, and multi-religious societies have great potential for conflicts between groups, races, religions and ethnic groups. The problems that arise because of diversity (ethnicity, religion, race, custom and so on) have become an inherent fact in various countries built on that diversity. Call it ethnic discrimination in America and Australia, ethnic tensions in Canada, the U.K. (King \& Butler, 2015). The majority of countries built from various ethnic groups or known as nation-states will face the same problem, namely the problem of cross-culture between one ethnic group and another. Disputes always arise because one ethnic group does not understand another ethnic group and/or does not respect it (Pieterse et al., 2018).

Furthermore, the existing problems continue to escalate, especially when drawn to the economic and/or political area. It is common knowledge; certain groups often use conflicts between ethnic groups for their economic and political interests. As a result, disputes continue and are deliberately set not to be resolved for that purpose.

To deal with the context of the problems, cultural diversity should be introduced from elementary school age, starting by introducing the differences between students in their class. For example, gender differences, parents' work backgrounds, learning abilities. This lesson will be very interesting if students are encouraged to recognise the differences between them without forgetting the similarities and togetherness as social members. Multi-cultural learning prioritises or allows differences inequality or vice versa equality in differences (Suswandari, 2017). In a society with cultural diversity, various problems and issues arise, including assimilation, prejudice and ethnocentrism (giving birth to superiority and inferiority). The last two things are more inseparable parts of the assimilation process (Amit \& Court, 2018; Nesterova, 2019; Starks, 2013). The factors that hinder the process of assimilation include a lack of knowledge of the culture at hand, fear of the strengths of other cultures (inferiority), overestimating one's own culture and looking down on other cultures or feeling superior. As a result of 
Jurnal Prima Edukasia, 9 (1), 2021 - 119

Uswatun Hasanah, Arita Marini, Arifin Maksum

the development of these obstacles in assimilation, suspicion and distrust often arise among the individuals who support the culture. Another result is that it is difficult to instil tolerance based on sympathy (Asbah, 2018; Mujib, 2016; Torres \& Tarozzi, 2020).

Looking at the facts, it can be said that awareness of the plurality of the population in Indonesia still has to be improved. They have not been able to appreciate the diversity and tolerance of the existing diversity. In essence, people who have a pluralist attitude will acknowledge that there are rights of other people to adhere to a religion/ethnicity/race/culture that is different from themselves (Anwar et al., 2020). Understanding Indonesian society in religion and culture has not shown a pluralist attitude; the existing phenomenon is that the attitude of religion and culture is heterogeneous. As Indonesian citizens, we should have a pluralist attitude towards diversity. This pluralist attitude can include aspects (1) accommodative, (2) selective, (3) integrative (4) cooperative (Erlich \& Gindi, 2019; Grant, 2016; Starks, 2013). Accommodative, in the sense that there is a willingness to accommodate various aspirations from various parties, selective, in the sense of choosing the most useful interests and problems, integrative, in balancing these various interests proportionally and cooperatively, in the sense of willingness to live together with anyone and willing to cooperate in a mundane. This attitude needs to be cultivated from an early age so that it can be embedded in the child so that he can be pluralist in the existing diversity context.

Cultivating a pluralist attitude at an early age can be facilitated by multi-cultural education. Multicultural education is expected to be able to answer the challenges of this era of globalisation. Education is one of the benchmarks and standards regarding how far a country can compete in the international world. The better the quality of education of a country, the more ready it is to face global competition. The main element in multi-cultural education is students' positions as parallel subjects; there is no superiority of one component of a student's culture against other students (Benson, 2018; Burnett \& McArdle, 2011; Dubbeld et al., 2019). In multi-cultural education, the expected outcomes are respect, tolerance, appreciation, and acceptance among diverse ethnic, racial, cultural and ability groups; selfrespect; and an understanding of the interdependence of groups and individuals. Teachers using this approach emphasise how students are similar and what they have in common but fail to address the power difference between the White middle class and the poor and minority groups (Talib et al., 2016). Thus this multi-cultural education can train and build the character of students who can be democratic, humanist and pluralist in their environment. Multi-cultural education has a strategic position in contributing to peace-building and conflict management efforts because the fundamental values of this education are the cultivation and earthing of the values of tolerance, empathy and solidarity (Erbaş, 2019).

To tolerate means to disagree with a belief or practice but to refrain from rejecting it. Rejecting a practice thus goes beyond disagreement or disapproval. Rejection means to prevent or eliminate the practice. Normally, we accept what we agree with and reject what we disagree with, but in toleration, we do not reject that with which we disagree. This means that to tolerate means being able to accept all differences from all existing points of view. To become tolerant of the differences in other people, one must have insight and knowledge of religion and a sense of sensitivity to human relations (van Waarden, 2017).

In responding to this, researchers try to provide a solution to overcome various problems due to diversity. Here, researchers have developed a multi-cultural education-oriented digital teaching material to improve the pluralist attitudes of elementary school students. This teaching material is a collection of integrated thematic-based stories. It adapts to the national curriculum used and pays attention to student characteristics in thinking holistically and student language development (Lemke et al., 2004; Yosso, 2020). Researchers integrate multi-cultural values and pluralist attitudes into the story content. During the reading process, meaning consists of both input and output. The reader brings his experience to the reading passage and relates the vicarious experience in the reading material to his experience. They are reading as the process of taking meaning 1 to ', to get meaning' from ', language in print. Fletcher suggested that through a passage, the author stimulates the reader to construct ideas from his own experience (Fletcher, 1977; Tarchi, 2017). By reading the story, students will indirectly enter the story experience and interpret the story's message (Asadi, 2018). Thus, this process can foster a pluralist attitude in students where this attitude can develop moderate, balanced and proportional attitudes and avoid discrimination, prioritise deliberation to reach consensus, and recognise the strengths and weaknesses of themselves and others. 
Multi-cultural education is very important given since elementary school. Multi-cultural education is a process of cultivating a way of life to respect and tolerate the diversity of cultures that live in a pluralistic society (Chen, 2016; Qodriyah \& Wangid, 2015). With the provision of multi-cultural education, it is hoped that there will be mental flexibility towards ethnic groups between races and religions so that national unity is not easily broken. In the context of Indonesia, which is known for its content which is full of diversity, multi-cultural education becomes a very strategic model to be able to manage diversity creatively so that conflicts that arise as a result of social transformation and reform can be managed intelligently and become part of the enlightenment of the nation's life in the future (Anwar et al., 2020). Multi-cultural education is very relevant to be implemented in supporting the democratisation process, in multi-cultural education, there are several things related to; recognition of human rights, non-discrimination and striving for social justice (Pang, 2019).

Also, with this multi-cultural education, a person can live quietly in a different cultural environment from his own. Indonesian society is a pluralistic society and even the most pluralistic in the world. Therefore, for this plurality to not develop into a threat of disintegration, efforts must be made to manage it properly. With this multi-cultural education, a person can live quietly in a cultural environment that is different from what he has $(\mathrm{Wu} \& \mathrm{Li}, 2018)$. Indonesian society is a pluralistic society and even the most pluralistic in the world. Therefore, for this plurality to not develop into a threat of disintegration, efforts must be made to manage it properly. With this multi-cultural education, a person can live quietly in a cultural environment that is different from what he has. Indonesian society is a pluralistic society and even the most pluralistic in the world. Therefore, for this plurality to not develop into a threat of disintegration, efforts must be made to manage it properly.

The novelty of this research includes digital teaching materials oriented to multi-cultural education that has been designed by integrating multi-cultural values into the teaching materials used informal learning. The multi-cultural values developed include inclusive values (openness), values prioritising dialogue (active), humanitarian values (humanist), tolerance values, help each other values, justice values (democratic), equality and fraternity values between nations and between nations, being kind would have thought, love the homeland (Grant, 2016; McGlynn, 2009; Nuryadi et al., 2020). Teaching material is a collection of simple story texts made thematic integratively by incorporating multi-cultural values into the context of the story. Also, there is an implementation of multi-cultural values in powerpoints and videos packaged as links. The development of this teaching material made in digital form is in line with developments and innovations in education and the current digital era. This digital teaching material is also very relevant in this Covid-19 pandemic, where all face-to-face learning in class switches to distance learning. The results of this study can provide contributions and solutions for education practitioners to instil multi-cultural education since elementary school age to create a pluralist generation of youth with diversity. Besides, through multi-cultural education-oriented digital teaching materials, students' attitudes and mindsets will be more open to understanding and appreciating diversity. The multi-cultural values contained in this teaching material are indirectly expected to increase students' pluralistic attitudes.

\section{Method}

This study aims to analyse the effectiveness of digital teaching materials on multi-cultural education to improve students' pluralist attitudes. The type of method used is a quantitative method with a quasi-experimental design. It uses a one-group pretest-posttest design with a control group design, namely a research design that contains a pre-test before being given treatment and a post-test after being given treatment. Thus, it can be more accurate because it can compare before and after being treated. The one-group pretest-posttest design implementation with control group design is carried out twice, namely before the experiment $\left(\mathrm{O}_{1}\right)$ is called the pre-test. After the experiment $\left(\mathrm{O}_{2}\right)$ is called the posttest, at the same time, the constellation can be seen in Table 1.

Table 1. One-Group Pretest-Posttest Constellation with Control-Group Design

\begin{tabular}{ccc}
\hline Pre-test & Treatment & Postest \\
\hline $\mathrm{O}_{1}$ & $\mathrm{X}$ & $\mathrm{O}_{2}$ \\
\hline
\end{tabular}

The research instrument used a questionnaire as a reference for measuring students' pluralist attitudes. The instruments used by researchers include indicators of pluralist attitudes, among others (1) 
Jurnal Prima Edukasia, 9 (1), 2021 - 121

Uswatun Hasanah, Arita Marini, Arifin Maksum

accommodative, (2) selective, (3) integrative (4) cooperative (Grant, 2016; Hobson \& Cresswell, 1993). The sample in this study was 108 elementary school students of class V in the Setiabudi sub-districtusing the probability sampling technique. It takes a sample that provides equal opportunities for everyone who does not have a member. The advantage of the probability method is that this method can calculate the sampling error from the data obtained from the respondent. In contrast, in the non-probability method, the error of the population will not be obtained by the respondent (Gall et al., 2003).

The data analysis technique used is descriptive statistics and t-test. The purpose of the t-test is to determine the hypothesis in this study, namely to determine whether there are differences in pre-test and post-test. The data in this study were managed with statistical calculation tools, the SPSS version 22 application.

\section{Result and Discussion}

\section{Result}

The results of this study explain the effectiveness of multi-cultural value-based teaching materials statistically in improving students' pluralist attitudes. The research results can be seen in Table 2.

Table 2. Pre-test and Post-test results

\begin{tabular}{lccc}
\hline & & Treatment & \\
\hline & & Pre-test & Posttest \\
\hline $\mathrm{N}$ & & 108 & 108 \\
& Mean & 63.42 & 81.97 \\
& Std. Deviation & 9,713 & 7,222 \\
& Std. Mean Error & 971 & 722 \\
\hline
\end{tabular}

The calculations in Table 2 show that the score is average before using teaching materials was 63.42 and after being given treatment, got an average score of 81.97. These results indicate a descriptive difference in the average results of the initial pluralist attitudes before and after using digital teaching materials based on multi-cultural education. After the results of the comparison between the pre-test and post-test are obtained, the next result is the correlation between the pre-test and post-test can be seen in Table 3.

Table 3. Correlation Calculation Results

\begin{tabular}{cccc}
\hline & $\mathrm{N}$ & Correlation & Sig. \\
\hline $\begin{array}{c}\text { Pretest } \\
\text { Posttest }\end{array}$ & 108 & 608 &, 000 \\
\hline
\end{tabular}

Table 3 shows that the correlation coefficient of the students' pluralist attitude scores before and after is 0.608. The following is the Paired Sample correlation shown in Table 4.

Table 4. Paired Samples Test

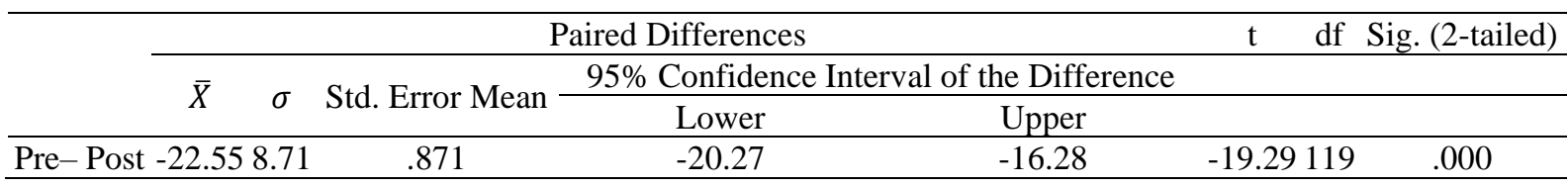

Table 4 shows an average difference of $=-22,550$ which means that the pluralist attitude score is higher after using multi-cultural value-based digital teaching materials. Thus, there is a significant difference between the results before and after using multi-cultural value-based digital teaching materials.

Based on the study results, the average before using digital teaching materials based on multicultural values was 63.42 , and after being given treatment, it increased the average score to 84.7 . The statistical score was $t=-19,294$ with a db of 99 and a significant number. or $p$-value $0.000<0.005$. The data obtained above shows that multi-cultural value-based digital teaching materials are one of the solutions that can be used to improve students' pluralist attitudes. 
Jurnal Prima Edukasia, 9 (1), 2021 - 122

Uswatun Hasanah, Arita Marini, Arifin Maksum

\section{Discussion}

Based on the findings in the study, it is stated that the existence of this multi-cultural value-based teaching material can effectively improve students' pluralist attitudes. The results of this study are relevant to the research conducted by (Erlich \& Gindi, 2019; Khatoon et al., 2011; Stevens \& Charles, 2005) where multi-cultural education can have a positive impact on students in developing pluralist attitudes.

After being given the learning treatment using multi-cultural value-based digital teaching materials, students become familiar with multi-cultural values packaged in the form of messages from simple stories. The conditions that arise after using this teaching material, students show attitudes willing to accept input and respect the opinions of others, accept the differences that his friends have, prioritise the public interest over his self and are willing to make friends and groups with anyone without differentiating their ethnicity, race and religion. This attitude is an implementation of someone who has a pluralist attitude. If this product is provided on an ongoing basis with a structured program, it is possible that we can further instil a culture of plurality in students.

According to research (Erbaş, 2019; Kim \& So, 2018; Pang, 2019), in implementing multicultural education in elementary schools, in designing multi-cultural education, the government must pay attention to the dimensions of multi-cultural education, namely (1) content integration, namely integrating various cultures and groups to illustrate basic concepts, generalisations and theories in subjects/disciplines, (2) the knowledge construction process, which brings students to understand the cultural implications of a subject (discipline), (3) an equity pedagogy, which is to adjust teaching methods to student learning to facilitate diverse student academic achievement. Both in terms of race, culture or social, (4) prejudice reduction, namely identifying the racial characteristics of students and determining their teaching methods (5) training groups to participate in sports activities, interacting with all staff and students of different ethnic and racial backgrounds to create an academic culture (Broom, 2019; Buzinski et al., 2018; Dahm, 2017). Of course, this is very supportive of research conducted by researchers where researchers instil multi-cultural education in students through content integration packaged in the form of teaching materials.

This teaching material product is a concrete development of creativity in implementing multicultural education in elementary schools. Teaching materials made by researchers are oriented towards the integration of multi-cultural values into teaching materials used informal learning. The multi-cultural values developed include inclusive values (openness), values prioritising dialogue (active), humanitarian values (humanist), tolerance values, values helping, justice (democratic), equality and brotherhood between nations and between nations, being kind. I would have thought, love the homeland (Grant, 2016; McGlynn, 2009; Nuryadi et al., 2020). In inclusive values, this value considers that the truth is embraced by one group, also embraced by other groups. This value recognises pluralism in a community or social group, promising to prioritise the principle of inclusiveness, leading to growing sensitivity to the unique possibilities that exist (Gurgel, 2015; Kuusisto \& Kallioniemi, 2014).

In the value of prioritising dialogue (active) with dialogue, different understandings about something that are owned by each of the different groups can be deepened mutually without harming each party. The result of putting dialogue first is a close relationship, mutual understanding, respect, trust, and help. As for the value of tolerance in social life, tolerance is understood as a manifestation of recognising and respecting human rights (Marini, 2017). Freedom of belief means the absence of compulsion in matters of religion, freedom of thought or opinion, freedom of association, and so on. Value of help as a social being, humans cannot live alone even though they have everything. Wealth is abundant so that what he wants can easily be fulfilled, but he cannot live alone without the help of other people and may never feel happiness. The value of justice (democratic) justice is a comprehensive term in all forms, be it cultural, political and social justice. Justice itself is a form that every human being gets what he needs, not what he wants (Rouhiainen \& Vuorisalo, 2019; Shatara et al., 2020). The value of equality and brotherhood between nations and between nations and kind thinking of seeing someone or another group by looking at the positive side and with this model will be no one group with another group will blame each other. So that harmony and peace will be created. As for the aspect of homeland love, in this case, it does not mean narrowly; it is not chauvinism that boasted of one's own country and insulted others, nor was it hostile to other countries. However, a broad and humane nationality 
Jurnal Prima Edukasia, 9 (1), 2021 - 123

Uswatun Hasanah, Arita Marini, Arifin Maksum

encourages living in harmony and peace with other nations (Waghid \& Davids, 2014). The appearance of this teaching material is as follows:
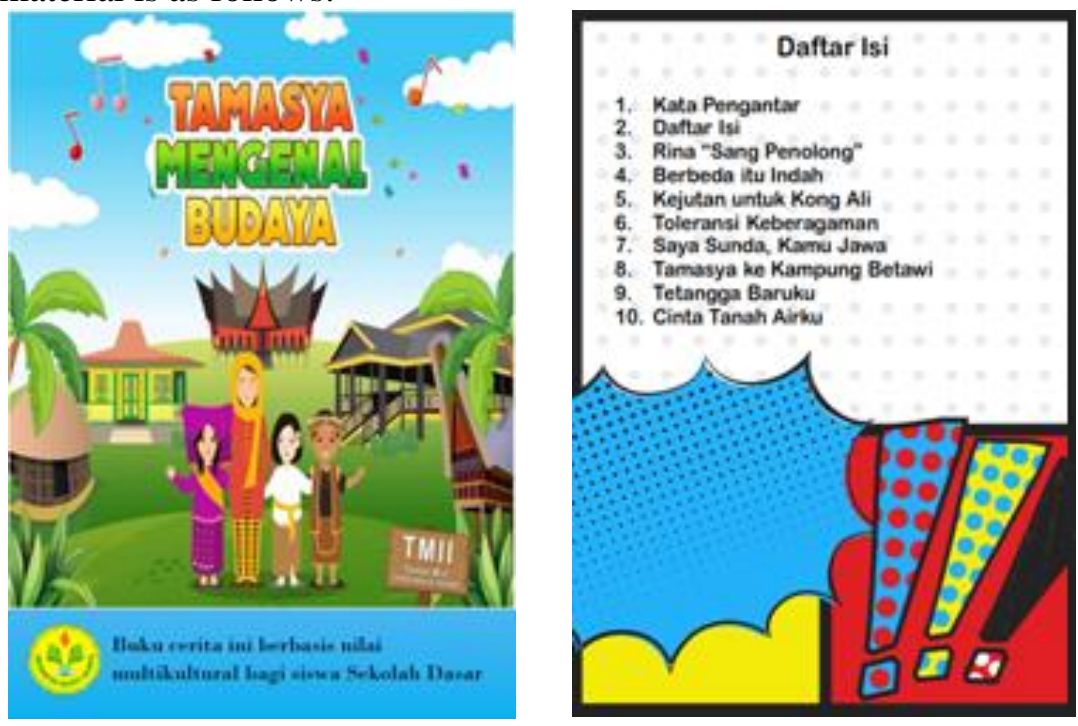

Figure 1. View of The Book

So in education, multi-cultural values include open values, democratic values, active values, tolerance values, help-helping values, equality values, kind thoughts and the value of love for the country (Baehr, 2017). The teacher instils these values to students in the teaching and learning process; these values are expected to influence students' attitudes to accept and appreciate differences. Also, this teaching material is made in digital form to make it easier for students and teachers to access it anywhere and anytime, especially during this pandemic. Through digital teaching materials oriented to multicultural education, it can instil a pluralist attitude in students. If this product is implemented in elementary school age students, its development will indirectly have an impact on their attitudes in the relationship. This is certainly positive in creating harmony and peace between students. This is by the research results (Watkins et al., 2016; Watkins \& Noble, 2016), which states that pluralism is the existence or tolerance of ethnic diversity or cultural groups in a society or country, as well as the diversity of beliefs or attitudes in an agency, institution and so on. Tolerance is needed to realise and support the concept. Tolerance without a pluralistic attitude will not guarantee the achievement of lasting inter-religious harmony and vice versa (Baehr, 2017; Marini et al., 2018). Thus, digital teaching materials oriented to multi-cultural education developed by researchers can improve the pluralist attitudes of elementary school students.

\section{Conclusion}

Based on the stages of research and development that has been passed, the conclusions of this study are as follows: digital teaching materials oriented to multi-cultural education developed in this study are proven valid, practical. They have the potential to affect the pluralist attitudes of elementary school students. The results of this study can provide contributions and solutions for education practitioners to instil multi-cultural education since elementary school age to create a pluralist generation of youth with diversity.

This study also explains that the importance of multi-cultural education is integrated into learning. Teaching materials based on multi-cultural values can make students more appreciative and tolerant of differences in their class. The recommendation of this research for teachers is an input that needs to focus on educating children, especially in elementary schools (Talib et al., 2016). Teachers must have sufficient insight into appreciating cultural diversity from an economic, linguistic and religious perspective. This insight is the basis for a teacher so that his attitude and behaviour show the same attitude and always respects the differences that exist. Teachers must directly apply anti-discriminatory attitudes towards students, either directly or integrated into learning. The teacher must immediately take action, such as stopping students' actions who are laughing and explaining that laughing at someone 
Jurnal Prima Edukasia, 9 (1), 2021 - 124

Uswatun Hasanah, Arita Marini, Arifin Maksum

else's accent. A dialect is an act that is not praiseworthy, and in the academic world, it is not justified because it should be full of nuances of mutual respect.

There are suggestions for students where students are the nation's next-generation that all parties must consider. If this multi-cultural value can be instilled from an early age, of course, he will become full of respect and tolerance in diversity when he is an adult. This attitude is not something instant but must be trained and accustomed to being cultured in students. The existence of multi-cultural valuebased teaching materials will indirectly teach them always to appreciate the differences around them.

This research's recommendation is the need for a curriculum model based on multi-cultural education. The education system provides a critical function of the need for a framework of attitudes and values to survive a democratic society. The government is obliged to incorporate multi-cultural education into all subjects in elementary schools to encourage students to love multiculturalism in Indonesia more to foster a love of the country without differences in ethnicity, race, religion and culture. Of course, starting from lesson planning, goals, materials teaching, media to evaluation instruments need to be integrated with multi-cultural values to produce graduates who love diversity.

\section{References}

Amit, N. A., \& Court, D. (2018). Contemporary Israeli theory and philosophy of education: Major trends and practical implications in the multi-cultural construction of Israeli education. Curriculum and Teaching, 33(2), 23-46. https://doi.org/10.7459/ct/33.2.03

Anwar, H., Arsyad, L., \& Mobonggi, A. H. (2020). The management of culture and environment of madrasah: Its implementation and challenges in industrial revolution era 4.0. Jurnal Prima Edukasia, 8(2), 188-198. https://doi.org/10.21831/jpe.v8i2.33488

Asadi, I. A. (2018). Reading comprehension subgroups in Arabic: A simple but not a multiplicative model. Reading \& Writing Quarterly, 34(4), 281-290. https://doi.org/10.1080/10573569.2017.1387835

Asbah, K. A. (2018). Education for multiculturalism among Arab Youth in Israel. Diaspora, Indigenous, and Minority Education, 12(1), 1-13. https://doi.org/10.1080/15595692.2017.1381951

Baehr, J. (2017). The varieties of character and some implications for character education. Journal of Youth and Adolescence, 46(6), 1153-1161. https://doi.org/10.1007/s10964-017-0654-z

Benson, C. (2018). Celebrating the rich resources represented by African multilingualism and multiculturalism in education: discussant paper. Current Issues in Language Planning, 19(2), 218-225. https://doi.org/10.1080/14664208.2017.1353336

Broom, C. A. (2019). Rethinking belonging in western nations: Theorising the public commons as a shared pluralistic community. Journal of International Social Studies, 9(2), 75-93. https://iajiss.org/index.php/iajiss/article/view/421

Burnett, B., \& McArdle, F. (2011). Multiculturalism, education for sustainable development (ESD) and the shifting discursive landscape of social inclusion. Discourse, 32(1), 43-56. https://doi.org/10.1080/01596306.2011.537070

Buzinski, S. G., Clark, J., Cohen, M., Buck, B., \& Roberts, S. P. (2018). Insidious assumptions: How pluralistic ignorance of studying behavior relates to exam performance. Teaching of Psychology, 45(4), 333-339. https://doi.org/10.1177/0098628318796919

Chen, S. (2016). Dawning of hope: Practice of and reflections on indigenous teacher education in Taiwan. Policy Futures in Education, 14(7), 943-955. https://doi.org/10.1177/1478210316656312

Dahm, R. (2017). Can pluralistic approaches based upon unknown languages enhance learner engagement and lead to active social inclusion? International Review of Education, 63(4), 521543. https://doi.org/10.1007/s11159-017-9636-3

Dubbeld, A., Hoog, N. de, den Brok, P., \& de Laat, M. (2019). Teachers' attitudes toward multiculturalism in relation to general and diversity-related Burnout. European Education, 51(1), 16-31. https://doi.org/10.1080/10564934.2017.1401435

Erbaş, Y. H. (2019). A qualitative case study of multi-cultural education in Turkey: Definitions of 
Jurnal Prima Edukasia, 9 (1), 2021 - 125

Uswatun Hasanah, Arita Marini, Arifin Maksum

multiculturalism and multi-cultural education. International Journal of Progressive Education, 15(1), 23-43. https://doi.org/10.29329/ijpe.2019.184.2

Erlich, R. R., \& Gindi, S. (2019). Are civics teachers different from teachers of other disciplines in their handling of controversial issues? Education, Citizenship and Social Justice, 14(2), 118-130. https://doi.org/10.1177/1746197918767082

Fletcher, P. M. (1977). The child's concept of reading: Its relationship with cognitive development and reading achievement [The College at Brockport].

https://digitalcommons.brockport.edu/ehd_theses/930

Gall, M. D., Gall, J. P., Borg, W. R. D., \& Gall, J. P. (2003). Educational research: An introduction (7th ed.). Pearson Education Inc.

Grant, C. A. (2016). Depoliticization of the language of social justice, multiculturalism, and multicultural education. Multicultural Education Review, 8(1), 1-13. https://doi.org/10.1080/2005615X.2015.1133175

Gurgel, R. (2015). Building strong teacher-student relationships in pluralistic music classrooms. Music Educators Journal, 101(4), 77-84. https://doi.org/10.1177/0027432115574554

Hobson, P., \& Cresswell, R. (1993). Parental rights, education and liberal tolerance. Discourse: Studies in the Cultural Politics of Education, 14(1), 44-51. https://doi.org/10.1080/0159630930140104

Khatoon, S., Rehman, S., \& Ajmal, M. (2011). Teaching in multi-cultural classroom- assessing current programs of teachers' training in Pakistan. International Journal of Humanities and Social Science, 1(6), 70-78. http://www.ijhssnet.com/journal/index/167

Kim, J. H., \& So, K. (2018). Understanding the "Other": Rethinking multiculturalism in South Korea through gadamer's philosophical hermeneutics. International Journal of Multicultural Education, 20(1), 102-117. https://doi.org/10.18251/ijme.v20i1.1509

King, E., \& Butler, B. R. (2015). Who cares about diversity? A preliminary investigation of diversity exposure in teacher preparation programs. Multi-cultural Perspectives, 17(1), 46-52. https://doi.org/10.1080/15210960.2015.994436

Kuusisto, A., \& Kallioniemi, A. (2014). Pupils views of religious education in a pluralistic educational context. Journal of Beliefs and Values, 35(2), 155-164. https://doi.org/10.1080/13617672.2014.953296

Lemke, M., Sen, A., Pahlke, E., Partelow, L., Miller, D., Williams, T., Kastberg, D., \& Jocelyn, L. (2004). International outcomes of learning in mathematics literacy and problem solving: PISA 2003 results from the U.S. Perspective. Highlights. NCES 2005-003. U.S. Department of Education.

Marini, A. (2017). Character building through teaching learning process: lesson in Indonesia. PONTE International Scientific Researchs Journal, 73(5), 177-182. https://doi.org/10.21506/j.ponte.2017.5.43

Marini, A., Safitri, D., \& Muda, I. (2018). Managing school based on character building in the context of religious school culture (Case in Indonesia). Journal of Social Studies Education Research, 9(4), 274-294. https://doi.org/10.17499/jsser.11668

McGlynn, C. (2009). Integrating education: Parekhian multiculturalism and good practice. Intercultural Education, 20(4), 299-310. https://doi.org/10.1080/14675980903351938

Mujib, I. (2016). Multi-cultural education practices at religiously-based schools in Malang. Al-Albab, 5(2), 281. https://doi.org/10.24260/alalbab.v5i2.425

Nesterova, Y. (2019). Multiculturalism and multi-cultural education approaches to Indigenous people's education in Taiwan. Multicultural Education Review, 11(4), 253-270. https://doi.org/10.1080/2005615X.2019.1686561

Nuryadi, M. H., Zamroni, \& Suharno. (2020). The pattern of the teaching of multiculturalism-based civics education: A case study at higher education institutions. European Journal of Educational Research, 9(2), 799-807. https://doi.org/10.12973/eu-jer.9.2.799

Pang, Y. (2019). Formal education in China: A call for genuine multiculturalism Yunge Pang. Journal 
Jurnal Prima Edukasia, 9 (1), 2021 - 126

Uswatun Hasanah, Arita Marini, Arifin Maksum

of Graduate Studies in Education, 11(1), 33-36.

Pieterse, E., Greenberg, R., \& Santo, Z. (2018). A multi-cultural approach to digital information literacy skills evaluation in an Israeli college. Communications in Information Literacy, 12(2), 107-127. https://doi.org/10.15760/comminfolit.2018.12.2.4

Qodriyah, S. H., \& Wangid, M. N. (2015). Pengembangan SSP tematik integratif untuk membangun karakter kejujuran dan kepedulian siswa SD kelas II. Jurnal Prima Edukasia, 3(2), 177. https://doi.org/10.21831/jpe.v3i2.7222

Rouhiainen, H., \& Vuorisalo, T. (2019). Higher education teachers' conceptions of sustainable development: implications for interdisciplinary pluralistic teaching. Environmental Education Research, 25(12), 1713-1730. https://doi.org/10.1080/13504622.2019.1657069

Shatara, L. H., Barakat, M., \& Bourkiza, M. (2020). Understanding the minority voice in a pluralistic society: The case of Islamic Schools. International Journal of Educational Reform, 29(1), 60-76. https://doi.org/10.1177/1056787919877140

Starks, C. (2013). Connecting multiculturalism, sustainability, \& teacher education: A Case for linking Martin Luther King Streets \& the power of place. Multicultural Education, 21(1), 33-37.

Stevens, R., \& Charles, J. (2005). Preparing teachers to teach tolerance. Multi-cultural Perspectives, 7(1), 17-25. https://doi.org/10.1207/s15327892mcp0701_4

Suswandari, S. (2017). Local history of Jakarta and multi-cultural attitude (historical local study of Betawi ethnic). JETL (Journal Of Education, Teaching and Learning), 2(1), 93. https://doi.org/10.26737/jetl.v2i1.142

Talib, M.-T., Loima, J., Paavola, H., \& Patrikainen, S. (2016). Multi-cultural education and intercultural education: Is there a difference Gunilla Holm and Harriet Zilliacus 11. Dialogs on Diversity and Global Education, October 2016. https://doi.org/10.3726/978-3-653-02064-9/3

Tarchi, C. (2017). Comprehending expository texts: The role of cognitive and motivational factors. Reading Psychology, 38(2), 154-181. https://doi.org/10.1080/02702711.2016.1245229

Torres, C. A., \& Tarozzi, M. (2020). Multiculturalism in the world system: towards a social justice model of inter/multi-cultural education. Globalisation, Societies and Education, 18(1), 7-18. https://doi.org/10.1080/14767724.2019.1690729

van Waarden, B. (2017). Teaching for toleration in pluralist liberal democracies. Democracy \& Education, 25(1), 1-12. https://lirias.kuleuven.be/1806547?limo=0

Waghid, Y., \& Davids, N. (2014). Muslim education and its (In)commensurability with multiculturalism: Some thoughts on the imaginative madrassah. Policy Futures in Education, 12(1), 124-130. https://doi.org/10.2304/pfie.2014.12.1.124

Wu, L., \& Li, Y. (2018). Incorporating a maple project of multi-cultures art in college mathematics teaching. Journal of Education and Learning, 7(5), 42. https://doi.org/10.5539/jel.v7n5p42

Yosso, T. J. (2020). Critical race media literacy for these urgent times. International Journal of Multicultural Education, 22(2), 5-13. https://doi.org/10.18251/ijme.v22i2.2685 